\title{
Gadai Deposito Sebagai Jaminan Kredit (Studi Kasus Bank Tabungan Negara Cabang Solo)
}

\author{
Dina Mardika Ramadani \\ Magister Kenotariatan Fakultas Hukum Universitas Islam Indonesia Yogyakarta Indonesia \\ Jl. Cik Di Tiro No. 1, Yogyakarta Indonesia \\ dinamardika04@gmail.com
}

\begin{abstract}
This study aims to determine, first, the implementation of credit agreements with deposit guarantees, whether the binding of time deposit guarantees is an accessoir agreement in credit guarantees and second, how is the legal settlement when there is a default at the Solo Branch of Bank Tabungan Negara (BTN). This research uses a juridical-empirical approach with both field and literature studies and is carried out by describing and reporting in detail and systematically about pawn deposits as credit guarantees at the Solo Branch of BTN. The results of the study concluded is first, the implementation of a credit agreement with a deposit guarantee at the Solo Branch of BTN is by: (1) the credit applicant fills out and signs a self-financing loan application form; (2) Preparation and signing of the Self-funding Credit Agreement and power of attorney; (3) The submission of the deposit slip is followed by the making and signing of the deed of pledge of deposit; (4) if all of the above documents are considered complete and perfect, an Approval for the Provision of Self-funding Credit is given and the credit applicant signs a Statement Letter; and (5) Loan disbursement by transferring to the debtor's savings account. Second, The binding of deposit guarantees is an accessoir agreement within the scope of credit guarantees, namely agreements that depend on the main agreement (i.e. credit agreements). Third, the legal settlement taken by the Solo Branch of BTN in the event of a default from the debtor is to implement the contents of the self-financing credit agreement and the pledge of deposit deed.
\end{abstract}

Key Words: Credit agreement; default; deposit guarantee

\begin{abstract}
Abstrak
Penelitian ini bertujuan untuk mengetahui, pertama, pelaksanaan perjanjian kredit dengan jaminan deposito, apakah pengikatan jaminan deposito berjangka merupakan perjanjian accessoir dalam jaminan kredit, dan kedua, bagaimana penyelesaian hukumnya ketika terjadi wanprestasi di Bank Tabungan Negara Cabang Solo. Penelitian ini menggunakan pendekatan yuridis-empiris dengan studi lapangan maupun studi pustaka dan dilakukan dengan cara menggambarkan dan melaporkan secara rinci dan sistematis mengenai gadai deposito sebagai jaminan kredit pada Bank Tabungan Negara Cabang Solo. Hasil penelitian menyimpulkan pertama, bahwa pelaksanaan perjanjian kredit dengan jaminan deposito di Bank Tabungan Negara Cabang Solo dengan cara: (1) pemohon kredit mengisi dan menandatangani formulir permohonan kredit swadana; (2) Pembuatan dan penandatanganan Perjanjian Kredit Swadana dan surat kuasa; (3) Penyerahan bilyet deposito diikuti pembuatan dan penandatanganan akta gadai deposito; (4) semua berkas di atas apabila sudah dianggap lengkap dan sempurna maka diberikanlah Persetujuan Pemberian Kredit Swadana dan pemohon kredit menandatangani Surat Pernyataan; dan (5) Pencairan kredit dengan cara mentransfer ke rekening tabungan debitur. Kedua, Pengikatan jaminan deposito merupakan perjanjian accessoir dalam lingkup jaminan kredit, yaitu perjanjian yang bergantung pada perjanjian pokoknya (yakni perjanjian kredit). Ketiga, penyelesaian hukum yang ditempuh Bank Tabungan Negara Cabang Solo jika terjadi wanprestasai dari debiturnya yaitu dengan melaksanakan isi dari perjanjian kredit swadana dan akta gadai deposito.
\end{abstract}

Kata-kata Kunci: Jaminan deposito; perjanjian kredit; wanprestasi 


\section{Pendahuluan}

Menurut Undang-Undang Perbankan Nomor 10 Tahun 1998 Pasal 1 ayat (1), bahwa Bank adalah: "Badan usaha yang menghimpun dana dari masyarakat dalam bentuk simpanan dan menyalurkannya kepada masyarakat dalam bentuk kredit atau bentuk lainnya. Fungsi penghimpunan dana dan fungsi penyaluran dana, terlihat dua hubungan hukum yaitu:

1. Hubungan hukum antara bank dan nasabah penyimpan dana, yang dituangkan dalam bentuk peraturan bank yang bersangkutan.

2. Hubungan hukum antara bank dan nasabah debitur, yang dituangkan dalam perjanjian kredit. ${ }^{1}$

Perjanjian kredit dalam praktek pada umumnya berbentuk suatu perjanjian standart atau perjanjian baku, yaitu perjanjian yang hampir seluruh klausulklausulnya sudah dibakukan oleh pemakainya, dan pihak lain pada dasarnya tidak mempunyai peluang untuk merundingkan atau meminta perubahan, yang belum dilakukan hanyalah beberapa hal saja, misalnya, yang menyangkut jenis, harga, jumlah, warna, tempat dan waktu serta beberapa hal lain yang spesifik dari obyek yang diperjanjikan, dengan kata lain yang dibakukan bukan formulir perjanjiannya tersebut melaunkan klausul-klausulnya. ${ }^{2}$

Menurut Undang-Undang Nomor 10 Tahun 1998 tentang Perbankan Pasal 1 butir 7, pengertian Deposito berjangka adalah simpanan yang penarikannya hanya dapat dilakukan pada waktu tertentu menurut perjanjian nasabah penyimpan (deposan) dengan bank dalam bentuk rupiah.

Deposito berjangka ini dikeluarkan berdasarkan Instruksi Presiden Republik Indonesia Nomor 28 Tahun 1958, Keputusan Direksi Bank Indonesia Nomor 7/8/Kep/UPUM/74. ${ }^{3}$ Jangka waktu pengambilan atau jatuh tempo pembayaran deposito berjangka berkisar antara satu bulan, tiga bulan, enam bulan dan dua belas bulan.

Dasar hukum deposito berjangka sebagai jaminan kredit tidak dijumpai secara khusus/belum mendapat pengakuan dalam perundang-undangan seperti UndangUndang Nomor 10 Tahun 1998 tentang Perbankan maupun peraturan pelaksanaannya yang berbentuk Peraturan Pemerintah, Peraturan Menteri Keuangan, Surat Keputusan Direksi Bank Indonesia serta Surat Edaran Bank Indonesia.

\footnotetext{
1 Sutan Remy Syahdeini, Kebebasan Berkontrak Dan Perlindungan Yang Seimbang Bagi Para Pihak Dalam Perjanjian Kredit Bank DI Indonesia, Institut Bankir Indonesia, Jakarta, 1993, hlm. 127.

${ }^{2}$ Ibid., hlm. 47.

3 H.M.N. Purwosutjipto, Pengertian Pokok. Hukum Dagang Indonesia, Hukum Surat Berharga, Jilid 7, Djambatan, Jakarta, 1987, hlm. 223.
} 
Ilmu hukum mengajarkan bahwa kebiasaan dapat juga menjadi suatu sumber hukum, begitu juga dalam praktek perkreditan, kebiasaan dan praktek perbankan dapat juga menjadi suatu dasar hukumnya. Praktek perbankan telah lazim melaksanakannya tetapi belum mendapat pengakuan dalam peraturan perundang-undangann, hal seperti ini tentu sah-sah saja selama tidak bertentangan dengan peraturan perundang-undangan yang berlaku. ${ }^{4}$

Dasar hukum deposito berjangka sebagai jaminan kredit adalah kebiasaan dan praktek perbankan di samping itu juga karena adanya asas kebebasan berkontrak yang memberi keleluasaan bagi bank untuk menafsirkan agunan sebagai keyakinan dan kesanggupan debitur untuk melunasi hutangnya seperti yang tercantum dalam Surat Edaran Bank Indonesia No. 23/6/UKU/tanggal 28 Februari 1991 tentang Jaminan Pemberian Kredit dan Surat Keputusan Direksi Bank Indonesia No. 23/69/Kep/Dir/tanggal 28 Februari 1991 tentang Jaminan Kredit, maka bank secara fleksibel menerima deposito berjangka sebagai jaminan kredit selain jaminan-jaminan konvensional yang telah diatur dalam peraturan perundang-undangan yang berlaku. Deposito berjangka yang akan dijadikan sebagai jaminan kredit harus diserahkan debitur (nasabah) kepada pihak bank yang sekaligus sebagai bank pemberi kredit (kreditur), kemudian atas deposito berjangka tersebut oleh bank diperiksa keasliannya, legalitasnya serta kebenaran dari isinya.

Menimbulkan masalah apabila karena sesuatu hal, misalnya pemenuhan kebutuhan konsumsi seseorang dan tuntutan untuk meningkatkan usaha (permodalan dalam usaha) seseorang yang mana dalam perkembangannya mengalami peningkatan sehingga mendorong seseorang untuk mengambil kredit di bank, tetapi karena tidak mempunyai benda tetap pada umumnya untuk dijadikan jaminan hanya mempunyai simpanan deposito berjangka sebagai investasinya dan depositonya belum jatuh tempo, maka dijadikanlah deposito berjangka tersebut sebagai jaminan kredit bank. Peranan lembaga perbankan di sini sangat penting dalam hal penyediaan dana melalui pemberian atau pelepasan kredit.

Kredit mempunyai arti kepercayaan, dengan dasar ini maka pemberian kredit merupakan pemberian kepercayaan. Kepercayaan dari pemberi kredit bahwa penerima kredit akan mempergunakan prestasi yang diterimanya sesuai dengan tujuan yang telah disepakati, dan mempunyai kemampuan atau kesanggupan untuk mengembalikan prestasi tersebut sesuai dengan jangka waktu dan syarat-syarat yang telah disetujui oleh kedua belah pihak. ${ }^{5}$ Adanya tenggang waktu antara pemberian prestasi dan penerimaan kembali prestasi

\footnotetext{
${ }^{4}$ Muhammad Djumhana, Hukum Perbankan di Indonesia, PT. Citra Aditya Bakti, Bandung, 1993, hlm. 14.

5 Ibid., hlm. 175.
} 
tersebut, maka dalam setiap pelepasan atau pemberian kredit dimungkinkan timbul adanya wanprestasi dari penerima kredit, supaya pihak bank terlepas atau terhindar dari kerugian atau setidak-tidaknya meminimumkan kerugian akibat wanprestasi dari debitur, maka bank melakukan tindakan pengamanan dan meminta calon nasabahnya agar mengikatkan suatu barang tertentu sebagai jaminan dalam pemberian kreditnya. Pasal 8 Undang-Undang Nomor 10 Tahun 1998 tentang Perbankan disebutkan bahwa, "Bank di dalam memberikan kredit, bank umum wajib mempunyai keyakinan atas kemampuan dan kesanggupan debitur untuk melunasi hutangnya sesuai dengan yang diperjanjikan." Perolehan keyakinan tersebut dengan cara bahwa, sebelum memberikan kredit pihak bank harus melakukan penilaian yang seksama terhadap watak (character), kemampuan (Capacity), kemampuan modal (Capital), agunan (Collateral) dan prospek usaha debitur atau kondisi ekonomi (Condition of economy). Hal ini merupakan prinsip-prinsip yang harus diterapkan dan berlaku umum di dunia perbankan, untuk menjamin penyaluran kredit sesuai fungsi dan tujuannya serta menghindari kerugian bagi pihak bank atas munculnya kasus kredit bermasalah. ${ }^{6}$ Jaminan kredit oleh calon debitur lebih dari itu diharapkan dapat membantu memperlancar proses analisa pemberian kredit dari bank, yang dengan demikian jaminan kredit (collateral) haruslah:

1. Secured artinya, jaminan kredit (collateral) tersebut dapat diadakan pengikatan secara yuridis formal sesuai dengan hukum dan perundangundangan yang berlaku, sehingga apabila dikemudian hari terjadi wanprestasi dari debitur, maka bank telah mempunyai alat bukti yang sempurna dan lengkap untuk menjalankan suatu tindakan hukum.

2. Marketable artinya, apabila jaminan tersebut harus, perlu dan dapat dieksekusi maka jaminan tersebut dapat dengan mudah dijual atau diuangkan untuk melunasi hutang debitur. ${ }^{7}$

Proses pemberian kredit perbankan dengan jaminan deposito berjangka antara bank dengan debitur (deposan) dibuat dengan suatu perjanjian yang dituangkan dalam perjanjian kredit bank yang terbagi atas perjanjian utang piutang (perjanjian pokok), dimana perjanjian ini mempunyai alasan sendiri (tidak tergantung pada adanya perjanjian lain), serta diikuti perjanjian accesoir (perjanjian ikutan/ perjanjian bantuan/perjanjian gadai) atau disebut dengan pactum de contrahendo yaitu perjanjian yang alasan dibuatnya bergantung pada adanya perjanjian lain (perjanjian pokoknya), yang berupa pemberian jaminan oleh pihak debitur kepada pihak bank. Pengikatan jaminan merupakan bentuk

${ }^{6}$ Sutarno, Aspek-Aspek Hukum Perkeditan pada Bank, Alfabeta, Jakarta, 2003, hlm. 93-94.

7 Hasanudin Rahman, Aspek-Aspek Pemberian Kredit Perbankan di Indonesia, PT. Citra Aditya Bakti, Bandung, 1995, hlm. 176. 
antisipasi oleh pihak bank apabila debitur tidak mau membayar kewajibannya atau utang-utangnya. Pembuktiannya dibuat suatu perjanjian secara tertulis, ini dimaksudkan supaya bank mempunyai alat bukti yang kuat atau sempurna dalam membuktikan adanya hubungan hukum yang dibuat bank dengan debiturnya untuk mengantisipasi kemungkinan terjadinya sesuatu yang tidak diinginkannya di kemudian hari. Perjanjian secara tertulis disini mengandung pengertian bahwa perjanjian kredit bank bisa dibuat dengan akta otentik dan bisa juga dibuat dengan akta di bawah tangan.

Perbedaan akta di bawah tangan dengan akta otentik adalah sebagai berikut:

1. Akta otentik adalah: suatu akta yang di dalam bentuk yang ditentukan oleh undang-undang, dibuat oleh atau dihadapan pejabat umum yang berwenang untuk itu di tempat dimana akta itu dibuat, sebagaimana diatur dalam Pasal 1868 KUHPerdata.

2. Akta di bawah tangan adalah akta yang sengaja dibuat untuk pembuktian oleh para pihak tanpa bantuan dari seorang pejabat, di buat antara para pihak yang berkepentingan saja, bentuknya tidak ditentukan oleh undang-undang, tanpa perantara atau tidak dihadapan pejabat umum yang berwenang.

Macam-macam jaminan dapat dibedakan menjadi dua yaitu:

1. Jaminan umum, jaminan menurut undang-undang diatur dalam Buku II KUHPerdata Pasal 1131, 1132, 1133 dan 1136; dan

2. Jaminan khusus, jaminan karena perjanjian yang meliputi

a. jaminan kerbendaan, meliputi

i. benda bergerak, lembaga jaminannya adalah gadai dan fidusia

ii. benda tak bergerak, lembaga jaminannya adalah hipotik dan credit verband

b. jaminan perorangan yaitu penanggungan (borgtocht), meliputi

i. personal guarantee

ii. corporate guarantee

Deposito berjangka sebagai jaminan kredit bank menurut kerangka hukum jaminan termasuk jaminan kebendaan dan merupakan benda bergerak yang tidak berwujud dan surat piutang atas nama, maka menurut hukum atau peraturan perundang-undangan yang berlaku menggunakan lembaga hukum gadai.

Deposito berjangka tidak dapat diperdagangkan sehingga dengan sendirinya juga tidak dapat dilelang. ${ }^{8}$ Prinsip bahwa apabila debitur lalai membayar hutangnya kemudian benda jaminannya dapat dilelang dan hasilnya dipergunakan untuk melunasi hutang debitur yang bersangkutan, hal ini adalah batal demi hukum. Cara atau penyelesaian dari bank untuk mengatasi kalau

\footnotetext{
${ }^{8}$ OP. Simorangkir, Seluk Beluk Bank Komersial, Aksara Persada Indonesia, Jakarta, 1986, hlm. 89.
} 
debitur wanprestasi biasanya dituangkan dalam klausul-klausul perjanjian kredit yang bersangkutan.

Berdasarkan uraian tersebut di atas mendorong penulis untuk melakukan penelitian yang berkaitan dengan deposito berjangka sebagai jaminan kredit. Penulis bermaksud menuangkan dalam bentuk tesis dengan judul "Gadai Deposito Berjangka Sebagai Jaminan Kredit di Bank Tabungan Negara (Persero) Cabang Solo".

\section{Rumusan Masalah}

Bertitik tolak pada latar belakang permasalahan yang telah dikemukakan di atas, maka penulis mengajukan permasalahan sebagai berikut: pertama, bagaimanakah pelaksanaan perjanjian kredit dengan jaminan deposito berjangka di Bank Tabungan Negara (Persero) Cabang Solo? Kedua, apakah pengikatan jaminan deposito berjangka merupakan perjanjian accessoir dalam lingkup lembaga jaminan kredit? Ketiga, bagaimanakah penyelesaiannya kalau terjadi wanprestasi dalam perjanjian kredit dengan jaminan deposito berjangka di Bank Tabungan Negara (Persero) Cabang Solo?

\section{Tujuan Penelitian}

Penelitian ini dilakukan dengan tujuan: pertama, mengetahui secara mendalam mengenai pelaksanaan perjanjian kredit dengan jaminan deposito berjangka di Bank Tabungan Negara (Persero) Cabang Solo; Kedua, mengetahui secara mendalam mengenai apakah pengikatan jaminan deposito berjangka merupakan perjanjian accessoir dalam lingkup lembaga jaminan kredit; Ketiga, mengetahui secara mendalam mengenai penyelesaiannya kalau terjadi wanprestasi dalam perjanjian kredit dengan jaminan deposito berjangka di Bank Tabungan Negara (Persero) Cabang Solo.

\section{Metode Penelitian}

\section{Subyek Penelitian}

1. Satu orang bagian Legal PT. Bank Tabungan Negara (Persero) Cabang Solo;

2. Satu orang bagian kredit PT. Bank Tabungan Negara (Persero) Cabang Solo;

3. Tiga orang nasabah PT. Bank Tabungan Negara (Persero) Cabang Solo

\section{Data Penelitian dan Bahan Hukum}

Data primer meliputi pihak-pihak yang diwawancarai terkait gadai deposito berjangka sebagai jaminan kredit di PT. Bank Tabungan Negara (Persero) Cabang Solo. Data Sekunder meliputi bahan hukum primer, antara lain: Kitab Undang- 
Undang Hukum Perdata Indonesia; Undang-Undang Nomor 10 Tahun 1998 tentang Perubahan Undang-Undang Nomor 7 Tahun 1992 tentang Perbankan; dan Perjanjian Kredit Bank. Sedangkan bahan hukum sekunder antara lain: literatur terkait seperti buku, majalah, artikel, jurnal, tesis, surat kabar dan artikel di media elektronik; dokumen perjanjian kredit dan pengikatan jaminannya dengan jaminan deposito berjangka pada PT. Bank Tabungan Negara (Persero) Cabang Solo serta dokumen yang lain yang berkaitan dengan penelitian ini. adapun bahan hukum tersier meliputi kamus hukum, ensiklopedia dan Kamus Besar Bahasa Indonesia.

\section{Teknik Pengumpulan dan Pengolahan Data}

Penulis memperoleh data primer melalui wawancara secara langsung dengan pihak-pihak yang berwenang dan mengetahui serta terkait mengenai gadai deposito berjangka sebagai jaminan kredit di PT. Bank Tabungan Negara (Persero) Cabang Solo dengan sistem wawancara bebas terpimpin, artinya terlebih dahulu dipersiapkan daftar pertanyaan sebagai pedoman tetapi masih dimungkinkan adanya variasi pertanyaan yang disesuaikan dengan situasi pada saat wawancara dilakukan. ${ }^{9}$ Kemudian penulis memperoleh data sekunder melalui peraturan perundang-undangan, literatur, karya-karya hukum dan bahan-bahan tertulis lainnya.

\section{Pendekatan Penelitian}

Pendekatan dalam penelitian hukum di sini terdiri atas pendekatan undangundang (statute approach) dan pendekatan kasus (case approach).

\section{Analisis Penelitian}

Analisis penelitian dalam penulisan tesis ini berupa penelitian deskriptif analitis, bermaksud untuk menggambarkan dan melaporkan secara rinci, sistematis dan menyeluruh mengenai segala sesuatu yang berkaitan dengan gadai deposito berjangka sebagai jaminan kredit pada PT. Bank Tabungan Negara (Persero) Cabang Solo. Data yang diperoleh selanjutnya dianalisis secara kualitatif. Data yang terkumpul kemudian dipilah dan dicari yang relevan dan representatif dengan permasalahan. Penulis menggunakan metode pendekatan secara yuridis empiris untuk menganalisis tentang sejauh manakah suatu peraturan perundang-undangan atau hukum yang sedang berlaku secara efektif ${ }^{10}$, hlm. 26.

${ }^{9}$ Soetrisno Hadi, Metodologi Research, Jilid II, Yayasan Penerbit Fakultas Hukum UGM, Yogyakarta, 1885, ${ }^{10}$ Soerjono Soekanto, Pengantar Penelitian Hukum, Universitas Indonesia, Jakarta, 1982, hlm. 52. 


\section{Hasil Penelitian dan Pembahasan}

\section{Pelaksanaan Perjanjian Kredit dengan Jaminan Deposito Berjangka di Bank Tabungan Negara (Persero) Cabang Solo}

Praktek perbankan menunjukkan bahwa seseorang yang dimaksud untuk mendapatkan kredit dari bank, memulai langkahnya dengan mengajukan permohonan kredit. Adapun tatacara permohonan atau pemberian kredit dengan jaminan deposito berjangka di PT. Bank Tabungan Negara (Persero) Cabang Solo adalah sebagai berikut:

1. Pertama-tama debitur PT. Bank Tabungan Negara (Persero) Cabang Solo datang ke bank dengan membawa identitas diri seperti, KTP atau SIM yang masih berlaku dan membawa deposito berjangka ke Bagian Pelayanan Kredit.

2. Bagian Pelayanan Kredit menyediakan formulir Permohonan Kredit Swadana untuk diisi dan ditandatangani oleh debitur. Formulir permohonan kredit swadana ini terbagi dua bagian dalam pengisiannya yaitu;

a. Bagian yang harus diisi oleh pemohon kredit yang meliputi, data pemohon, data penghasilan pemohon, dan data mengenai kredit, di samping itu pemohon kredit juga diharuskan mematuhi peraturan pemohon kredit yang ditentukan secara sepihak oleh PT. Bank Tabungan Negara (Persero) Cabang Solo.

b. Bagian yang hanya dikhususkan untuk diisi oleh pejabat bank yang berwenang yaitu, mengenai catatan verifikasi dan keputusan. Permohonan kredit swadana ini dibuat rangkap dua, satu untuk debitur dan yang satu lagi untuk arsip bank.

3. Pembuatan dan penandatanganan perjanjian kreditt Swadana antara PT. Bnak Tabungan Negara (Persero) Cabang Solo dengan debitur yang isinya ditentukan secara sepihak oleh pihak bank, di samping itu sebagai bagian yang tidak terpisahkan dari perjanjian kredit, disertakan pula pemberian kuasa yang dibuat dalam bentuk surat kuasa. Pemberian kuasa tersebut adalah pemberian kuasa penuh kepada pihak bank sebagai kreditur untuk dan atas nama pemberi kuasa (debitur) untuk melakukan pemblokiran atas surat-surat deposito berjangka yang dijaminkan apabila debitur tidak dapat melaksanakan kewajibannya mengenai pembayaran hutang atau kredit dalam Perjanjian Kredit Swadana.

4. Debitur menyerahkan deposito berjangka dilanjutkan pembuatan dan penandatanganan Akta Gadai Deposito. Akta Gadai Deposito ini dibuat rangkap 2, satu untuk arsip bank dan satu lagi untuk debitur.

5. Semua berkas di atas dibawa ke Bagian Administrasi Kredit, di sini ada Legal Officer akan mengadakan pemeriksaan untuk menilai permohonan kredit dan 
meneliti syarat-syarat yang ditentukan, semisal salah satunya meneliti atau memeriksa mengenai jaminannya, dalam hal ini bilyet deposito berjangka mengenai keasliannya, legalitasnya serta kebenaran dari isinya, serta oleh Legal Officer ini akan ditentukan apakah permohonan itu dapat dipertimbangkan lebih lanjut oleh Loan Section Head atau Kepala bagian Kredit sebagai pejabat yang berwenang untuk memberikan persetujuan kredit swadana.

6. Setelah pemeriksaan oleh Legal Officer selesai dan syarat-syarat dalam pengajuan permohonan kredit swadana yang telah ditentukan oleh bank telah dipenuhi debitur dan telah dapat dianggap lengkap dan sempurna, maka persetujuan terhadap permohonan kredit diberikan oleh Kepala Bagian Kredit dengan mengeluarkan Surat Persetujuan Pemberian Kredit Swadana, apabila debitur menyetujui ketentuan dan syarat penyediaan fasilitas kredit menurut Surat Persetujuan Pemberian Kredit Swadana ini, maka sebagai tanda persetujuan debitur atas ketentuan dan syarat di dalam Surat Persetujuan Pemberian Kredit Swadana ini, hendaknya Surat Pernyataan yang dilampirkan pada surat ini, debitur tanda tangani dengan benar di atas materai Rp. 6.000,00

7. Kemudian pencairan kredit dilakukan dengan cara mentransfer dana sebesar kredit yang telah disetujui bank ke rekening tabungan debitur.

Menghadapi praktek perbankan dalam hal pemberian kredit yang dituangkan dalam perjanjian kredit yang bersifat baku atau standart tersebut di atas, debitur pada umumnya tidak dapat berbuat lain selain menyetujuinya, sebab jika tidak menyetujuinya berarti permohonan kreditnya gagal. Perjanjian baku atau standart seperti ini pada dasrnya tidak memberikan peluang kepada pihak lain (dalam hal ini debitur) untuk merundingkan atau meminta perubahan dari kreditur(dalam hal ini bank). Perjanjian yang berbentuk baku atau standart tersebut biasanya terdiri dari klausul-klausul yang sudah ditetapkan secara sepihak oleh bank selaku kreditur.

\section{Pengikatan Jaminan Deposito Berjangka Merupakan Perjanjian Accessoir dalam Lingkup Lembaga Jaminan Kredit}

Proses pemberian kredit perbankan dengan jaminan deposito berjangka antara bank dengan debitur (deposan) dibuat dengan suatu perjanjian yang dituangkan dalam perjanjian kredit bank yang terbagi atas perjanjian utang piutang (perjanjian pokok), dimana perjanjian ini mempunyai alasan sendiri (tidak tergantung pada adanya perjanjian lain), serta diikuti perjanjian accesoir (perjanjian ikutan/ perjanjian bantuan/perjanjian gadai) atau disebut dengan pactum de contrahendo yaitu perjanjian yang alasan dibuatnya bergantung pada adanya perjanjian lain (perjanjian pokoknya), yang berupa pemberian jaminan oleh pihak debitur kepada pihak bank. Uraian di atas dapat disimpulkan bahwa, 
pengikatan jaminan deposito berjangka merupakan perjanjian accessoir dalam lingkup lembaga jaminan kredit.

\section{Wanprestasi Dalam Perjanjian Kredit Dengan Jaminan Deposito Berjangka dan Penyelesaian Hukumnya.}

Kriteria debitur telah melakukan wanprestasi dalam perjanjian kredit dengan jaminan deposito berjangka yang ditetapkan oleh Bank Tabungan Negara (Persero) Cabang Solo adalah sebagai berikut:

1. Debitur tidak mampu melunasi seluruh kewajibannya dalam batas waktu yang telah ditentukan dalam perjanjian kredit swadana (jangka waktu pelunasan kredit);

2. Debitur tidak mampu melunasi kewajiban pembayaran bunga kredit selama 3 bulan (poin a dan poin b ini telah tercantum dalam Perjanjian Kredit Swadana di Bank Tabungan Negara (Persero) Cabang solo, yaitu dalam Pasal 6 ayat (1) Perjanjian Kredit Swadana tentang Pelaksanaan (eksekusi) Dana Jaminan (lihat lampiran halaman 8);

3. Jikalau debitur/peminjam dinyatakan lalai oleh bank untuk membayar kembali hutangnya kepada bank, baik pokok, bunga, denda dan lainnya. Poin c ini telah tercantum dalam Akta Gadai Deposito di Bank Tabungan Negara (Persero) Cabang Solo, yaitu dalam Pasal 2 (lihat lampiran halaman 13)

Penyelesaian Hukumnya/Upaya Hukumnya yang Ditempuh PT. Bank Tabungan Negara (Persero) Cabang Solo Apabila Terjadi Wanprestasai

Penyelesaian hukumnya/upaya hukumnya yang ditempuh PT. Bank Tabungan Negara (Persero) Cabang Solo apabila terjadi wanprestasi yang dilakukan debiturnya/peminjam kredit adalah sebagai berikut:

1. Bank setiap saat dapat mencairkan dana jaminan kredit yang berupa deposito berjangka, ini diatur dalam Pasal 6 ayat (1) Perjanjian Kredit Swadana tentang Pelaksanaan (eksekusi) Dana Jaminan. Untuk mencairkan dana jaminan sebagaimana disebutkan Pasal 6 ayat (1) di atas, debitur menyetujui dan sekaligus memberikan kuasa kepada Bank Tabungan Negara untuk membayar seluruh kewajiban bulanannya untuk pokok, bunga, denda dan biaya lainnya tanpa terlebih dahulu memberitahukan kepada pemilik dana jaminan, ini diatur dalam Pasal 6 ayat (2) dalam Perjanjian Kredit Swadana tentang Pelaksanaan (eksekusi) Dana Jaminan. Kuasa yang diberikan dalam perjanjian kredit swadana ini tidak dapat dicabut dan tidak akan berakhir karena sebabsebab yang tercantum dalam Pasal 1813 KUHPerdata atau dikarenakan sebab apapun, ini diatur dalam Pasal 6 ayat (3) Perjanjian Kredit Swadana (lihat lampiran halaman 8 dan 9). 
2. Jikalau peminjam dinyatakan lalai oleh bank untuk membayar kembali hutangnya kepada bank, baik pokok, bunga, denda dan lainnya, dan untuk itu pemberitahuan secara apapun juga tidak diperlukan, maka bank berhak untuk mencairkan seluruh deposito tersebut di atas untuk membayar seluruh hutang peminjam kepada bank baik pokok, bunga, denda dan biaya lainnya. Ketentuan ini diatur dalam Pasal 2 ayat (1) Akta Gadai Deposito di Bank Tabungan Negara (Persero) Cabang Solo (lihat lampiran halaman 13).

3. Pasal 2 ayat (1) Akta Gadai Deposito tersebut di atas ditegaskan lebih lanjut dalam Pasal 2 ayat (2) Akta Gadai Deposito, yaitu bahwa, pemberi gadai dengan ini juga memberi kuasa kepada bank untuk mencairkan deposito/ dana jamianan tersebut (lihat lampiran halaman 13).

4. Poin c di atas dipertegas lagi di dalam Pasal 4 Akta Gadai Deposito yaitu bahwa, Pemberi gadai dengan ini memberi kuasa kepada bank dengan hak substitusi, kuasa mana merupakan bagian yang tidak dapat dicabut kembali dan tidak akan berakhir karena sebab-sebab yang tercantum dalam Pasal 1813 KUHPerdata atau sebab-sebab lain apapun untuk:

a. Memperpanjang deposito berjangka yang digadaikan tersebut bila jangka waktu berakhir sampai dengan seluruh pinjaman (kredit) swadana tersebut telah dilunasi seluruhnya baik pokok, bunga, denda dan biaya-biaya lainnya.

b. Mencairkan seluruh deposito berjangka yang digadaikan berikut bunganya bila peminjam lalai.

c. Menerima hasil pencairan seluruh deposito berjangka yang digadaikan berikut bunganya untuk membayar seluruh pinjaman kepada bank baik pokok, bunga, denda dan biaya lainnya.

5. Pasal 5 Akta Gadai Deposito yang juga menegaskan mengenai penyelesaian hukum apabila debitur wanprestasi yaitu, yang mengatakan bahwa, Pemberi gadai menjamin bahwa deposito berjangka yang digadaikan, baik sekarang atau kemudian hari, tidak aka nada sitaan atau tuntutan dari pihak lain yang menyatakan mempunyai hak terlebih dahulu atau turut mempunyai hak atas deposito berjangka yang digadaikan ataupun tidak dijaminkan kepada pihak lain dengan cara apapun dan karenanya bank dibebaskan oleh pemberi gadai dari segala tuntutan mengenai hal-hal tersebut.

\section{Penutup}

Berdasarkan uraian yang disampaikan di atas, maka dapat disimpulkan sebagai beriku, pertama, bahwa pelaksanaan perjanjian kredit dengan jaminan deposito di Bank Tabungan Negara Cabang Solo dengan cara: (1) pemohon kredit mengisi dan menandatangani formulir permohonan kredit swadana; (2) 
Pembuatan dan penandatanganan Perjanjian Kredit Swadana dan surat kuasa; (3) Penyerahan bilyet deposito diikuti pembuatan dan penandatanganan akta gadai deposito; (4) semua berkas di atas apabila sudah dianggap lengkap dan sempurna maka diberikanlah Persetujuan Pemberian Kredit Swadana dan pemohon kredit menandatangani Surat Pernyataan; dan (5) Pencairan kredit dengan cara mentransfer ke rekening tabungan debitur. Kedua, Pengikatan jaminan deposito merupakan perjanjian accessoir dalam lingkup jaminan kredit, yaitu perjanjian yang bergantung pada perjanjian pokoknya (yakni perjanjian kredit). Ketiga, penyelesaian hukum yang ditempuh Bank Tabungan Negara Cabang Solo jika terjadi wanprestasai dari debiturnya yaitu dengan melaksanakan isi dari perjanjian kredit swadana dan akta gadai deposito.

\section{Daftar Pustaka}

\section{Buku}

Djumhana, Muhammad, Hukum Perbankan Di Indonesia, PT. Citra Aditya Bakti, Bandung, 1993.

Hadi, Soetrisno, Metodologi Research Jilid II, Yayasan Penerbit Fakultas Hukum Psikologi Universitas Gadjah Mada, Yogyakarta, 1885.

Purwosutjipto, H.M.N., Pengertian Pokok Hukum Dagang Indonesia, Djambatan, Jakarta, 1987.

Rahman, Hasanudin, Aspek-Aspek Pemberian Kredit perbankan di Indonesia, PT.Citra Aditya Bakti, Bandung, 1995.

Simorangkir, OP., Seluk Beluk Bank Komersial, Aksara Persada Indonesia, Jakarta, 1986.

Sjahdeini, Sutan Remy, Kebebasan Berkontrak Dan Perlindungan Yang Seimbang Bagi Para Pihak Dalam Perjanjian Kredit Di Indonesia, Institut Bankir Indonesia, Jakarta, 1993.

Soekanto, Soerjono, Pengantar Penelitian Hukum, Universitas Indonesia, Jakarta, 1982.

Sutarno, Aspek-Aspek Hikum Perkreditan pada Bank, Alfabeta, Jakarta, 2003. 